\title{
Milk production and percentages of fat and protein in Holstein breed cows raised in Rio Grande do Sul, Brazil
}

\author{
Produção de leite e porcentagens de gordura e proteína de bovinos \\ da raça Holandesa criados no Rio Grande do Sul, Brasil
}

\author{
Giovani Luis Feltes ${ }^{I^{*}}$ Vanessa Tomazetti Michelotti ${ }^{\mathrm{I}}$ Alan Miranda Prestes $^{\mathrm{I}}$ \\ André Padilha Bravo ${ }^{I}$ Carlos Bondan ${ }^{I I}$ Mariana de Almeida Dornelles ${ }^{I}$ \\ Fernanda Cristina Breda ${ }^{I}$ Paulo Roberto Nogara Rorato
}

ABSTRACT

The objective of this study was to identify a nonlinear regression model that better describes the milk production and the percentages of fat and protein curves, and to identify the season and age of calving that result in higher productions. For the analysis, 8,047 records of milk production and percentages of fat and protein obtained from 1,330 Holstein breed cows raised in Rio Grande do Sul, born from 1989 to 2011, were used. After determining the most appropriate nonlinear regression model, the identity of models and the equality of parameter tests for the different classes of season and age of calving were performed. Residual mean square, mean absolute deviation, mean squared prediction error and percentage of estimated curves per animal, indicated the Linear Hyperbolic Function (LHF) as the most appropriate to describe the milk production and the levels of fat and protein curves. Cows calving in the autumn and winter seasons yield higher quantities of milk and lower fat and protein content than those calved in the spring and summer seasons. Cows aged between 46 and 93 months at calving yield higher milk quantities, and those with calving age between 94 and 118 months produced more fat.

Key words: calving season, hyperbolic linear function, age at calving, identity model test.

\section{RESUMO}

Objetivou-se identificar o modelo de regressão não linear que melhor descreve as curvas de produção de leite e de porcentagens de gordura e proteína; a estação e idade ao parto que resultam em maiores produções. Nas análises, foram utilizados 8047 registros de produção de leite e porcentagens de gordura e proteína provenientes de 1330 vacas da raça Holandesa, criadas no Rio Grande do Sul, nascidas de 1989 a 2011. Após a definição do modelo de regressão não linear mais adequado, procedeu-se à realização do teste de identidade de modelos e de igualdade de parâmetros para as diferentes classes de estação e idade da vaca ao parto. O quadrado médio do resíduo, desvio médio absoluto, erro quadrático médio de predição e a porcentagem de curvas estimadas por animal apontaram a Função Linear Hiperbólica (FLH) como a mais adequada para descrever as curvas de produção de leite e teores de gordura e proteína. Vacas com ocorrência de partos nas estações de outono e inverno produzem maior quantidade de leite e menor teor de gordura e proteina do leite do que aquelas que parem nas estações de primavera e verão. Vacas com idades ao parto entre 46 e 93 meses produzem maior quantidade de leite e as com 94 a 118 meses, maior teor de gordura do leite.

Palavras-chave: estação de parto, função linear hiperbólica, idade ao parto, teste de identidade de modelos.

\section{INTRODUCTION}

The study of lactation curves through nonlinear regression models aims to predict milk production and its constituents from incomplete records in any one of the lactation stages with the least possible error. Knowledge and application of the estimates and predictions of the lactation curve are crucial in the decision-making process in breeding programs, as well as in management decisions (RODRIGUEZ, 2009).

Additionally, comparison of the curve's shape among the distinct animal groups, of different breed compositions, calving ages, herds, and other treatments of interest is of paramount importance, as information about the effectiveness of these

IDepartamento de Zootecnia, Centro de Ciências Rurais (CCR), Universidade Federal de Santa Maria (UFSM), Av. Roraima, 1000, Cidade Universitária, Camobi, 97105-900, Santa Maria, RS, Brasil. E-mail: feltesgiovani@gmail.com. ${ }^{*}$ Corresponding author.

"Centro de Pesquisa em Alimentação, Serviço de Análise de Rebanhos Leiteiros, Universidade de Passo Fundo (UPF), Passo Fundo, RS, Brasil. 
groups can be obtained through these comparisons, thus providing better control over production. Nevertheless, determining the best models to be employed is a difficult task, since one model may be adequate for analyzing the milk production curve of a certain population, but not suitable for another, due to the genetic and environmental specificities of each. Furthermore, different statistical criteria for selecting mathematical models are proposed in the literature, while some recommend minimizing adjustment errors, others emphasize the prediction ability or simplicity of the model (SILVEIRA et al., 2011).

The aim of this study was to identify a nonlinear regression model that best describes the milk production curves and percentages of fat and protein, and to apply the statistical identity model, equality of parameter test, and principal component analysis in order to determine calving seasons and age classes at calving, which result in higher milk yield, fat and protein content in the milk of Holstein breed cows raised in Rio Grande do Sul.

\section{MATERIALS AND METHODS}

The data used in this study were obtained from the Dairy Herds Analysis Service of the Universidade de Passo Fundo, and the statistical analyzes were performed at the Animal Breeding Laboratory of the Universidade Federal de Santa Maria. Eight thousand and forty-seven records of milk yield, percentage of fat, and protein of 1,330 cows, calved from 1989 to 2011, from 64 herds (average of 41 animals per herd) and distributed throughout the North and Northwest regions of Rio Grande do Sul, were used in these analyzes.

During the preparation of the working file, milk yield and percentages of fat and protein in testday (MYTD) were grouped in 10 monthly classes. The number of observations per month varied from 509 in the $10^{\text {th }}$ month, to 979 in the sixth month of lactation. Cows displaying milk yield, fat, and protein percentages with 3.5 standard deviations, above or below the population average, within the monthly class, and cows with less than four milk yield records during lactation, were excluded from the data file.

The age of dams at calving were divided into four periods, as follows: 22 to 45 months (743 observations); 46 to 57 months (384 observations); 58 to 81 months (153 observations); and 82 to 117 months of age ( 50 observations). The calving seasons were determined as follows: summer, December to February (356 observations); autumn, March to May (439 observations); winter, June to August (366 observations); and spring, September to November (169 observations).

The milk yield and percentages of fat and protein were analyzed using nine nonlinear regression models on the test-day, described by COBUCI et al. (2000) and MUÑOZ-BERROCAL et al.(2005), as follows: Brody I $\left(\mathrm{y}=\mathrm{ae}^{\mathrm{cn}}\right)$, Brody II $\left(\mathrm{y}=\mathrm{ae}^{-\mathrm{bn}}-\mathrm{ae}^{-\mathrm{cn}}\right)$, Cobuci (y = a-cn $+\ln (\mathrm{n}))$, Incomplete Gamma Function $\operatorname{IGF}\left(y=\mathrm{an}^{\mathrm{b}} \mathrm{e}^{-\mathrm{cn}}\right)$, Linear Hyperbolic $-\operatorname{LHF}(\mathrm{y}=\mathrm{a}+\mathrm{bn}+\mathrm{cl} / \mathrm{n})$, Inverse Polynomial - IPF $\left(y=n /\left(a+b n+c^{2}\right)\right.$, Quadratic Logarithmic - QLF (y = a +bn+cn $\left.{ }^{2}+\mathrm{dLog}(\mathrm{n})\right)$, Papajcsik and Bodero $\left(\mathrm{y}=\mathrm{ane}^{\mathrm{cn}}\right)$ and Parabolic Exponential PEF $\left(y=a e^{b n+c n 2}\right)$. In the models outlined, $y$ is the monthly milk yield, $\mathrm{n}$ is the lactation month, $\mathrm{a}, \mathrm{b}, \mathrm{c}, \mathrm{d}$ are the parameters of each model.

The statistical criteria used to determine the most appropriate model were as follows: residual mean square (RME); mean absolute deviation of residues (MAD), $\quad M A D=\frac{\sum_{i=1}^{n}\left|Y_{i}-\hat{Y}_{i}\right|}{n}$ mean squared prediction error (MSPE), $M S P E=\frac{\sum_{i=1}^{n}\left(Y_{i}-\hat{Y}_{i}\right)^{2}}{n}$ where $\mathrm{Yi}$ is the observed value, $\hat{\mathrm{Y}} \mathrm{i}$ the estimated value, and $n$ the size of the sample. In order to help determining the best model an index was calculated as follows: INDEX $=\mathrm{RME}+\mathrm{MAD}+\mathrm{MSPE}$.

Once the nonlinear regression model which best suited to model the trajectories of milk yield and fat and protein percentages were defined, the identity model and equality of parameters tests were conducted, as proposed by REGAZZI et al. (2003), and the following hypothesis evaluated: H01 = all parameters are equal; $\mathrm{H} 02$ = all a parameters are equal; $\mathrm{H} 03=$ all $\underline{b}$ parameters are equal and $\mathrm{H} 04=$ all c parameters are equal.

A principal component analysis was carried out using the SAS (2013) for evaluating the age classes of dam at calving in different seasons considering three characteristics simultaneously.

\section{RESULTS AND DISCUSSION}

For milk production, the lowest values for the residual mean square (RME), mean absolute deviation (MAD), mean squared prediction error (MSPE) and Index, were observed through Brody II followed by QLF and LHF (Table 1).

For protein percentage in milk, the lowest RME values (0.09) were observed through Brody I, IGF, LHF, PEF, and QLF models; however, the lowest MAD value was given by LHF, whereas the lowest MSPE value was given by QLF. For the percentages of fat in milk, the lowest RME value was observed by IGF, LHF, 
Table 1 - Models, residual mean square (RME), mean absolute deviation (MAD), mean squared prediction error (MSPE) and index for milk production and protein and fat percentages.

\begin{tabular}{|c|c|c|c|c|}
\hline \multirow{2}{*}{ Models } & \multirow[b]{2}{*}{ RME } & \multirow[b]{2}{*}{ MAD } & \multirow[b]{2}{*}{ MSPE } & \multirow[b]{2}{*}{ INDEX $^{*}$} \\
\hline & & & & \\
\hline & 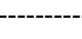 & lk yield & & 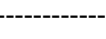 \\
\hline Brody I & 65.30 & 0.83 & 1.28 & 67.34 \\
\hline Brody II & 64.19 & 0.12 & 0.02 & 64.33 \\
\hline Cobuci & 64.86 & 0.61 & 0.78 & 66.25 \\
\hline IGF & 6428 & 0.28 & 0.11 & 64.67 \\
\hline LHF & 64.21 & 0.17 & 0.04 & 64.42 \\
\hline PEF & 64.62 & 0.55 & 0.48 & 65.65 \\
\hline IPF & 69.45 & 1.89 & 5.95 & 77.29 \\
\hline QLF & 64.20 & 0.15 & 0.02 & 64.37 \\
\hline Papajcsik & 80.33 & 3.48 & 18.62 & 102.43 \\
\hline Brody I & 0.09 & 0.10 & 0.0048 & 0.19 \\
\hline Cobuci & 0.16 & 0.21 & 0.0782 & 0.45 \\
\hline IGF & 0.09 & 0.03 & 0.0017 & 0.12 \\
\hline LHF & 0.09 & 0.02 & 0.0006 & 0.11 \\
\hline PEF & 0.09 & 0.04 & 0.0029 & 0.13 \\
\hline IPF & 0.21 & 0.26 & 0.1375 & 0.61 \\
\hline QLF & 0.09 & 0.20 & 0.0005 & 0.29 \\
\hline Papajcsik & 0.43 & 0.47 & 0.3964 & 1.29 \\
\hline Brody I & 0.79 & $\begin{array}{c}\text { ages of } \\
0.09\end{array}$ & 0.0062 & 0.94 \\
\hline Cobuci & 0.88 & 0.25 & 0.0685 & 1.19 \\
\hline IGF & 0.78 & 0.03 & 0.0748 & 0.88 \\
\hline LHF & 0.78 & 0.01 & 0.0004 & 0.79 \\
\hline IPF & 0.94 & 0.30 & 0.0362 & 1.27 \\
\hline QLF & 0.78 & 0.02 & 0.0006 & 0.80 \\
\hline Papajcsik & 1.20 & 0.53 & 0.0451 & 1.77 \\
\hline
\end{tabular}

${ }^{*}$ Index $=$ RME + MAD + MSPE.

and QLF (0.78) whereas the criteria MAD, MSPE and INDEX indicated only LHF as the best function.

LHF exhibited the best index ( $\mathrm{I}=\mathrm{RME}+$ MAD + MSPE) values for percentage of protein and fat in milk, and the third best for milk production (Table 1). When estimating the milk yield, fat and protein percentage curves per animal, the LHF curve resulted in $100 \%$ convergence. Comparing the curves observed-estimated by the model Brody II (data not shown) it was found that they are similar, the same was observed for LHF and QLF.

As a result, LHF was used to estimate the milk yield curves and percentage of fat and protein for different seasons and calving age. MUÑOZ BERROCAL et al. (2005) also noted the best adjustment for LHF on the average lactation curve of Murrah buffaloes. CRUZ et al. (2009) and COBUCI et al. (2000) reported that LHF did not adjust well to the lactation curve of Guzera cows, which can be explained by differences in the lactation curve shape of this breed when compared to the Holstein.

The identity model test between the different age classes at calving was notable for milk yield and percentage of fat in the milk $(\mathrm{P}<0.05)$, indicating that the curves differ from one another (Figure 1A and 1C). Hence, the equality of parameters test was favored, and it was found that only parameter $\mathrm{C}$ can be equal for estimating the milk yield curve in the four age groups $(\mathrm{P}<0.05)$. In order to estimate the fat percentage curve, parameters $\mathrm{A}, \mathrm{B}$, and $\mathrm{C}$ were notably equal $(\mathrm{P}<0.05)$, suggesting that one of the parameters may be fixed, but not all three simultaneously, since the identity model test yielded significant results.

For the milk yield, the estimates of parameter A for the age classes at calving, ranged from 33.56 to 38.02 (Table 2), higher than those 

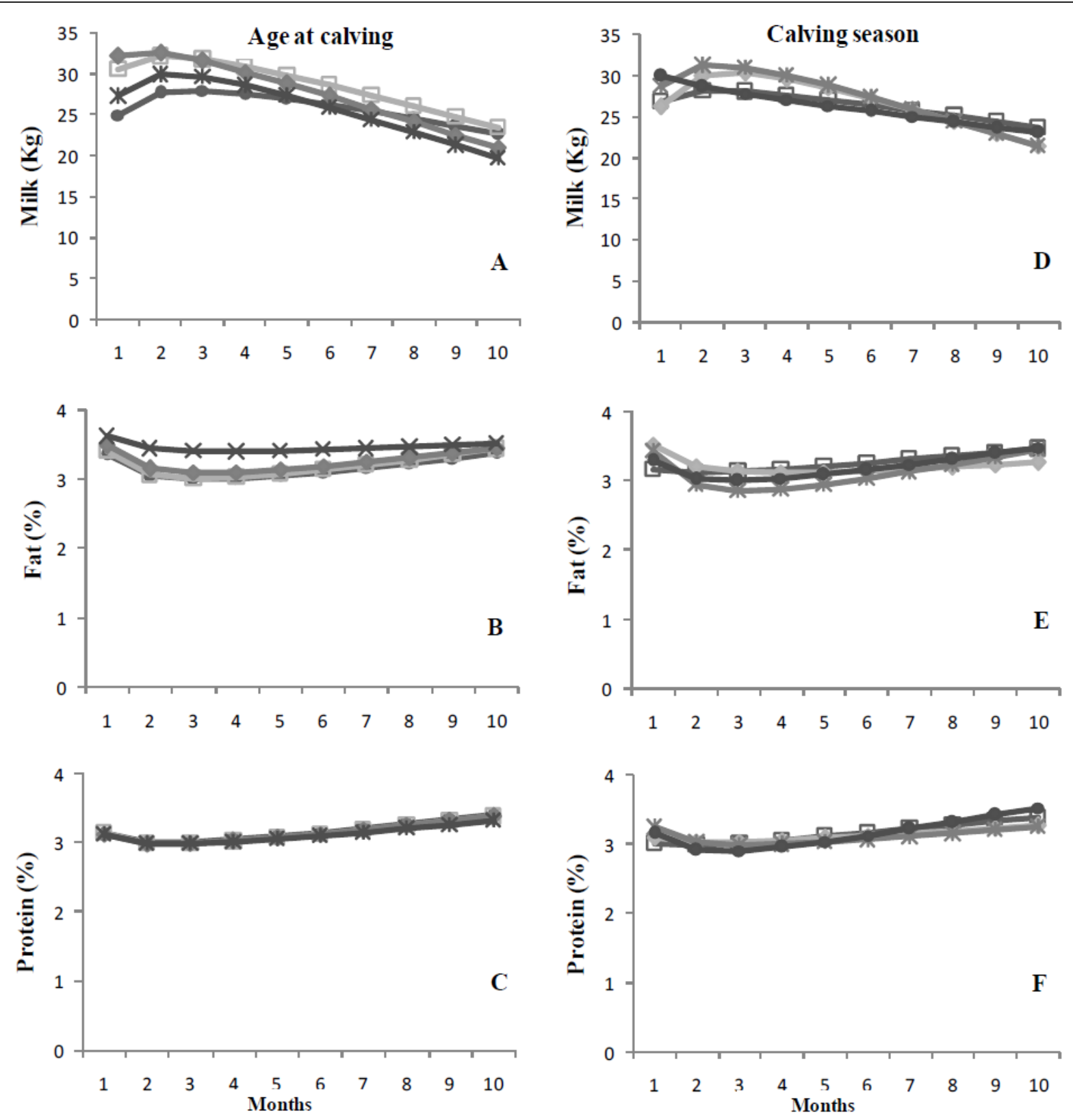

Figure 1 - Estimated milk yield, fat and protein curves by Linear Hyperbolic function in different seasons $(\bullet$ spring; $\square$ summer; $\bullet$ autumn; * winter) and age classes at calving ( $\bullet 22$ to 45 months; $\square 46$ to 69 months; $\bullet 70$ to 93 months; * 94 a 118 months).

reported by CRUZ et al. (2009) in the Guzera and Sindhi breeds. According to these authors, this parameter is related to the initial yield, thus negative values are responsible for atypical lactation curves, indicating initial output lower than zero. Estimates of parameters $\mathrm{B}$ and $\mathrm{C}$ ranged from -1.70 to -1.01 and -8.54 to -4.02 , respectively. For the percentage of fat and protein in milk, parameters $\mathrm{B}$ and $\mathrm{C}$ estimates were positive, due to the absence of peak in the trajectory of these two characteristics.
In figure 1A lower milk production for animals aged between 22 and 45 months (22.70 and $28.01 \mathrm{~kg}$ ) and 94 to 118 months (19.73 to $29.91 \mathrm{~kg}$ ) can be observed. Similar outcomes were observed by SOUZA et al. (2010) in the Holstein breed in Paraná. Animals calving between 22 and 45 months of age were characterized by low peak yield, declining slightly in subsequent months, and as being one of the most productive classes from the sixth month onwards, in other words, these animals did not display a well-defined

Ciência Rural, v.46, n.4, abr, 2016. 
Table 2 - Estimates of the Linear Hyperbolic Function ${ }^{*}$ parameters for the different age classes and calving seasons.

\begin{tabular}{|c|c|c|c|c|c|c|c|c|c|}
\hline \multirow{2}{*}{ Age classes of dam at calving } & \multicolumn{3}{|c|}{ 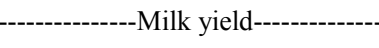 } & \multicolumn{3}{|c|}{ 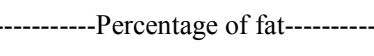 } & \multicolumn{3}{|c|}{----Percentage of protein---- } \\
\hline & $\mathrm{a}$ & $\mathrm{B}$ & $\mathrm{c}$ & $\mathrm{a}$ & $\mathrm{b}$ & $\mathrm{c}$ & $\mathrm{a}$ & $\mathrm{b}$ & $\mathrm{c}$ \\
\hline Age 1 & 33.56 & -1.01 & -7.57 & 2.50 & 0.08 & 0.78 & 2.66 & 0.07 & 0.42 \\
\hline Age 2 & 38.02 & -1.40 & -6.08 & 2.46 & 0.09 & 0.86 & 2.64 & 0.07 & 0.43 \\
\hline Age 3 & 37.88 & -1.65 & -4.02 & 2.59 & 0.08 & 0.82 & 2.64 & 0.07 & 0.41 \\
\hline Age 4 & 37.58 & -1.70 & -8.54 & 3.18 & 0.03 & 0.41 & \multirow{2}{*}{\multicolumn{3}{|c|}{ 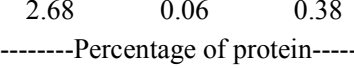 }} \\
\hline \multirow{2}{*}{ Calving seasons } & ----- & Milk yiel & -------- & ------ & entage & ------ & & & \\
\hline & $\mathrm{a}$ & $\mathrm{b}$ & $\mathrm{c}$ & $\mathrm{a}$ & $\mathrm{b}$ & $\mathrm{c}$ & $\mathrm{a}$ & $\mathrm{b}$ & $\mathrm{c}$ \\
\hline Season 1 & 31.77 & -0.77 & -4.14 & 2.91 & 0.05 & 0.21 & 2.79 & 0.06 & 0.16 \\
\hline Season 2 & 38.84 & -1.62 & -11.01 & 2.78 & 0.04 & 0.71 & 2.85 & 0.04 & 0.22 \\
\hline Season 3 & 38.72 & -1.64 & -8.37 & 2.07 & 0.13 & 1.24 & 2.64 & 0.06 & 0.55 \\
\hline Season 4 & 29.32 & -0.64 & 1.25 & 2.51 & 0.09 & 0.69 & 2.34 & 0.11 & 0.71 \\
\hline
\end{tabular}

${ }^{*}$ Linear hyperbolic function: $\mathrm{y}=\mathrm{a}+\mathrm{bn}+\mathrm{c} 1 / \mathrm{n}$, where: $\mathrm{y}$ is the monthly phonotypical trait expression, $\mathrm{n}$ is the lactation month, and $\mathrm{a}, \mathrm{b}$ and $\mathrm{c}$ parameters of the functions.

yield peak, which was also verified by VAL-ARREOLA et al. (2004) in dairy cattle raised in Mexico.

Cows calving between 46 and 69 months of age presented higher milk yield throughout the whole lactation period (23.41 to $32.18 \mathrm{~kg}$ ). These findings match those by NORO et al. (2006) and ANDRADE et al. (2007) in Holstein breed cattle raised in Rio Grande do Sul and São Paulo, respectively. Animals calving between 70 and 93 months of age presented high yield during early lactation $(32.21 \mathrm{~kg})$, decreasing sharply after the peak yield, resulting in lower yields from the $6^{\text {th }}(25.76 \mathrm{~kg})$ to $10^{\text {th }}$ month $(20.98 \mathrm{~kg})$ of lactation.

OLIVEIRA et al. (2007) noted in crosses of Holstein and Gyr breeds cows raised in Minas Gerais, that multiparous cows resulted in adjusted mean production $48.9 \%$ higher than in primiparous cows, which may be related to the development of the mammary gland and higher capacity of food intake (SOUZA et al., 2010).

Animals calving between 94 and 118 months of age displayed the highest fat content, with lower variation after the second month of lactation $(3.40 \%$ to $3.52 \%)$. The remaining age groups resulted in similar fat percentage curves, with higher percentages observed within the first month (3.36\%), followed by a slightly decline $(3.00 \%)$ before increasing again from the $6^{\text {th }}$ month onwards $(3.11 \%)$ (Figure 1C). Similar results were obtained by NORO et al. (2006).

For the protein percentage, the identity test proved to be non-significant $(\mathrm{P}<0.05)$, in other words, there was no difference with respect to the percentage of protein in the milk among the four age periods of the calving cows. The percentages of protein in the milk ranged from $3.12 \%$ to $3.40 \%$ throughout lactation (Figure 1B). NORO et al. (2006) reported higher milk protein content in cows aged from 33 to 45 months, and lower in primiparous cows. SOUZA et al. (2010) reported no correlation between the lactation order and fat and protein content in milk.

The identity model test carried out for the various calving seasons was significant for milk yield and percentage of fat and protein in milk $(\mathrm{P}<0.05)$. Thus, the equality of parameters test was employed, in which for all measured conditions (1D, $1 \mathrm{E}$ and $1 \mathrm{~F}$ ), no equality was observed. The estimates of parameters $\mathrm{A}$, $\mathrm{B}$, and $\mathrm{C}$ for calving seasons are displayed in table 2 .

It was observed that cows that calved in autumn and winter exhibited higher yields from the $2^{\text {th }}$ (31 and $27 \mathrm{~kg}$, respectively) to the $6^{\text {th }}$ month $(28$ and $25 \mathrm{~kg}$, respectively), likely due to an increased availability of quality pasture and greater thermal comfort. Milk yield for the four seasons were similar from the $7^{\text {th }}$ month of lactation onwards (Figure 1D).

NORO et al. (2006) noted that the highest yield seen in winter, in Rio Grande do Sul, was associated with forage consumption, such as the temperate poaceae of the Lolium and Avena genera, whereas during the summer months, lower quality tropical poaceae of the Cynodon, Sorghum, and Pennisetum are available. Furthermore, SOUZA et al. (2010) reported that the animals beginning lactation in spring, reached lactation peak in summer, therefore requiring higher levels of nutrient intake, however, the consumption of pasture results in the filling of the rumen, and aggravates the effects of the heat stress.

Differences in the protein percentage amidst seasons were observed from the $7^{\text {th }}$ month onwards, exhibiting higher percentages for cows that calved in spring and summer. In general, protein content varied from $2.91 \%$ to $3.53 \%$ (Figure 1E). 
The fat percentages were lower in cows that calved in the winter season, from the $2^{\text {th }}$ to the $7^{\text {th }}$ month of lactation. Cows that calved in autumn presented lower fat percentages in the $9^{\text {th }}$ and $10^{\text {th }}$ month. The highest fat percentages stemmed from cows that calved in summer, ranging from $3.17 \%$ to $3.47 \%$ (Figure $1 \mathrm{~F}$ ).

It was noted through the principal component analysis that the three characteristics were important to explain the variation in the data when considering the age and calving season of the cow, simultaneously. Milk yielding resulted in correlation coefficients with the principal components 1 and 2 equals to -0.93 and 0.22 ; fat content equals to 0.75 and 0.67 ; and protein contents of 0.90 and 0.32 , respectively. As observed in figure 2 , cows calving at 94 to 118 months of age in winter time were benefited by climatic conditions that proportioned best thermal comfort and availability of quality food, permitting them to be the best milk producers for this period (Quadrant II, Figure 2). The calving of these cows in spring, summer and autumn, resulted in lower milk yield and higher fat and protein concentration in milk (Quadrant I and IV, Figure 2).

A strong influence of the seasons on milk production and protein percentage was observed, cows that calved in autumn and winter were the major milk producers regardless of age, (Quadrant II and III, Figure 2) where as those calving in spring and summer presented higher milk protein percentages (Quadrant IV, Figure 2). Cows calving between 94 and 118 months of age produced milk with higher fat content.

\section{CONCLUSION}

The Linear Hyperbolic function (LHF) can be used to describe milk yield and the percentages of fat and protein curves between different ages and calving seasons.

Cows calving during the autumn and winter seasons yield higher quantities of milk and lower fat and protein content than those that calved in spring and summer.

In general, cows calving between 46 and 93 months of age yield higher quantities of milk. Cows calving between 94 and 118 months of age are more susceptible to environmental changes. Those calving in winter have higher milk production, those calving in summer and autumn showed a higher fat percentage, and those calving in spring showed a higher protein percentage.

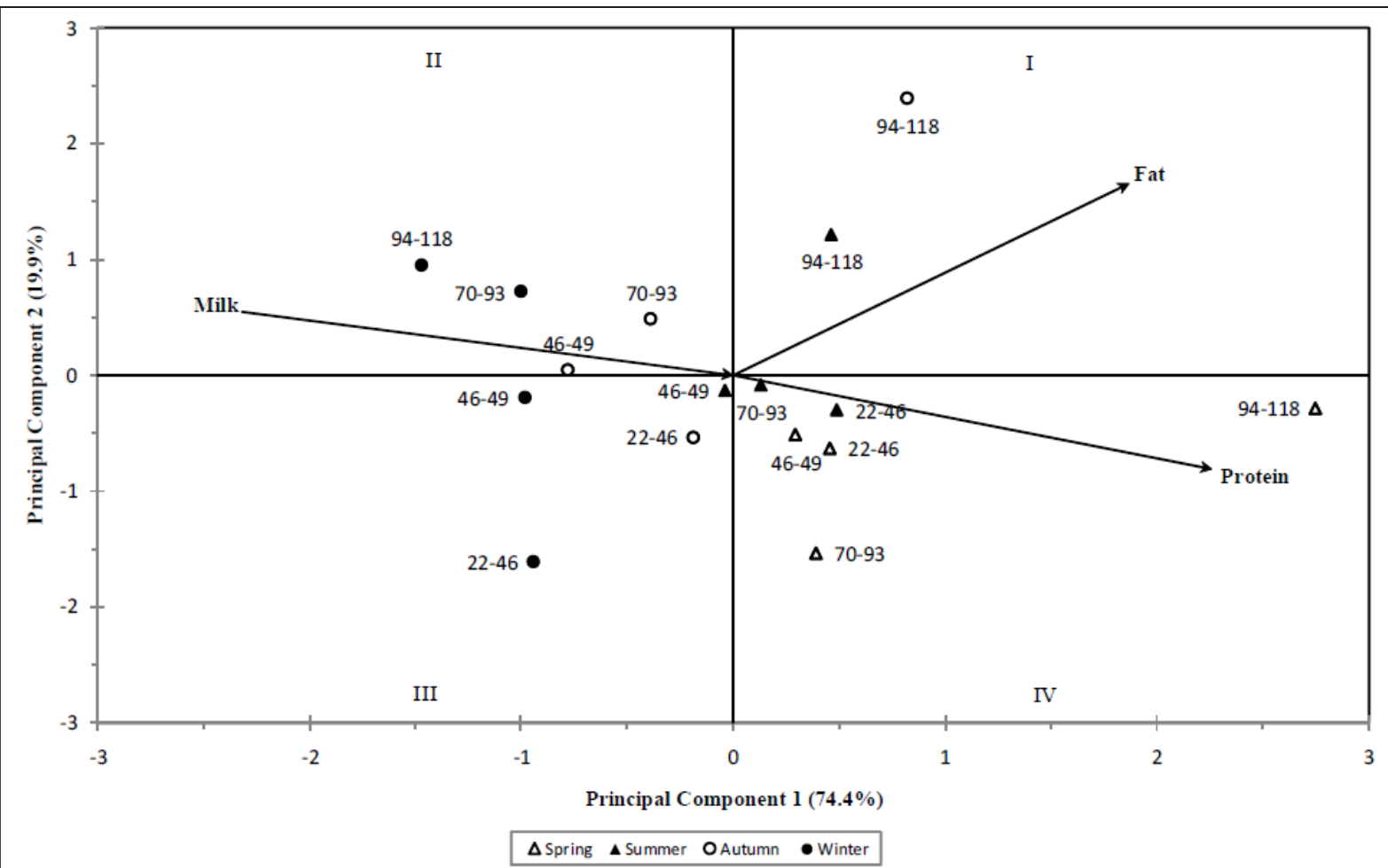

Figure 2 - Two-dimensional graph of the principal components based on the age classes (22-46; 46-49; 70-93 and 94-118 months) and calving seasons for the variable milk productions (milk, $\mathrm{kg}$ ) and fat and protein content $(\%)$.

Ciência Rural, v.46, n.4, abr, 2016. 


\section{ACKNOWLEDGEMENTS}

The authors are grateful to Coordenação de Aperfeiçoamento de Pessoal de Nível Superior (CAPES) and Conselho Nacional de Desenvolvimento Científico e Tecnológico (CNPq) for the financial support.

\section{REFERENCES}

ANDRADE, L.M. et al. Genetic and environmental effects on milk yield and somatic cell count of Holstein cows. Revista Brasileira de Zootecnia, v.36, n.2, p.343-349, 2007. Available from: $<$ http://www.scielo.br/scielo.php?script=sci arttext\&pid $=$ S1516-35982007000200010 $>$. Accessed: Dec. 20 2014. doi: 10.1590/S1516-35982007000200010.

COBUCI, J.A. et al. Lactation Curve in Guzera Breed. Revista Brasileira de Zootecnia, v.29, n.5, p.1332-1339, 2000. Available from: <http://www.scielo.br/scielo.php?pid=S151635982000000500011\&script $=$ sci_arttext $>$. Accessed: Oct. 22, 2013. doi: 10.1590/S1516-35982000000500011.

CRUZ, G.R.B. et al. Estimates of lactation curve parameters of cattle. Archivos de Zootecnia, v.58, n.224, p.695-704, 2009. Available from: $<$ http://scielo.isciii.es/scielo.php?pid=S000405922009000400007\&script $=$ sci_arttext $>$. Accessed: Jul. 20, 2015. ISSN 0004-0592.

MUÑOZ-BERROCAL, M. et al. Use of some mathematical models to study the lactation curve of Murrah buffaloes and their cross bress breds under a semi-extensive system in the state of São Paulo. Archivos Latino americanos de Produción Animal, v.13, n.1, p.19-23, 2005. Available from: <http://www.bioline.org.br/ request?la05003>. Accessed: Sept. 22, 2013. ISSN 1022-1301.

NORO, G. et al. Fatores ambientais que afetam a produção e a composição do leite em rebanhos assistidos por cooperativas no Rio Grande do Sul. Revista Brasileira de Zootecnia, v.35, n.3, p.1129-1135, 2006. Available from: <http://www.scielo.br/scielo. php?script=sci_arttext\&pid=S1516-35982006000400026>. Accessed: Aug. 09, 2014. doi: 10.1590/S1516-35982006000400026.
OLIVEIRA, H.T.V. et al. Lactation curves adjusted by incomplete gamma function for crossbred F1 Holstein-Gyr cows. Arquivo Brasileiro de Medicina Veterinária e Zootecnia, v.59, n.1, p.233-238, 2007. Available from: <http://www.scielo.br/scielo. php? script $=$ sci_arttext $\&$ pid $=$ S01 02-09352007000100037 $>$. Accessed: Jun. 20, 2015. doi: 10.1590/S0102-09352007000100037.

REGAZZI, A.J. Tests for model identity and parameter equality with nonlinear regression models in data from randomized complete block design. Revista Ceres, v.50, n.287, p.9-26, 2003. Available from: <http://www.scielo.br/scielo.php?script=sci arttext\&pid=S0034-737X2010000300005>. Accessed: May 15, 2014. doi: 10.1590/S0034-737X2010000300005.

RODRIGUEZ, M.A.P. Efeitos não genéticos nos parâmetros do modelo de Michaelis-Menten para curvas de lactação. 2009. 70f. Dissertação (Mestrado em Zootecnia) - Universidade Federal de Lavras, MG.

SAS Institute Inc. Statistical Analysis System user's guide Version 9.4ed. Cary, 2013. 556p.

SILVEIRA, F.G. et al. Cluster analysis applied to nonlinear regression models selection to growth curves of crossed lambs. Ciência Rural, v.41, n.4, p.692-698, 2011. Available from: $<$ http://www.scielo.br/scielo.php?script=sci_arttext\&pid=S010384782011000400024\&lng=en\&nrm=iso $>$. Accessed: Nov. 12, 2014. doi: 10.1590/S0103-84782011000400024.

SOUZA, R. et al. Milk production and quality of Holstein cows in function of the season and calving order. Revista Brasileira de Saúde e Produção Animal, v.11, n.2, p.484-495, 2010. Available from: <http://revistas.ufba.br/index.php/rbspa/article/ view/1494/984>. Accessed: Oct. 15, 2014.

VAL-ARREOLA, D. et al. Study of the lactation curve in cattle on farms in Central Mexico. Journal of Dairy Science, v.87, n.11, p.3789-3799, 2004. Available from: <http://www. journalofdairyscience.org/article/S0022-0302(04)73518-3/ pdf>. Accessed: Dec. 12, 2014. doi: 10.3168/jds.S00220302(04)73518-3. 